\title{
Migration as a Livelihood Diversification Strategy of Poor Rural Household in Edo State, Nigeria
}

\author{
Stanley O. ABIZU \\ Department of Development studies \\ University of Fort Hare \\ South Africa
}

\begin{abstract}
Migration is largely seen as key component of livelihood diversification strategies to overcome poverty in difficult situations in developing nations. The paper examines migration as a livelihood strategy adopted by the rural households to overcome poverty in Edo State. Majority of the rural households in Edo State use migration as a way to mitigate against risk and unforeseen circumstances. In order for livelihood diversification, households take the decision to send members of their families to urbanised cities, where they could gainfully be employed and start sending remittance back home as way of diversifying the family income sources. These remittances therefore, form substantial part of the household's incomes. The paper therefore, shows that remittance incomes from migrants positively contribute to improving the living standard of the households. They also provide a foundation for sustainable income security in the families of the migrants, and assist in empowering, the household to overcome poverty.
\end{abstract}

Keywords: Diversification, Empowering, Livelihoods, Income, Migration, Remittance

\subsection{Introduction}

Over the years migration has become a tool used to overcome the risky situations in most countries in Africa. Rural households in Africa have continued to increase their economic activities diversification. It is gradually becoming clear that rural households in Nigeria are expanding in to non- farm activities as a means of improving livelihood and reducing poverty. Increasing non- agricultural income diversification livelihood strategy has be growing in Nigeria for quite some times now. Thus, there is an increasing support for non-farm diversification opportunities for rural households in the developing countries (Asmah, 2011). Studies have suggested increasing activities among rural households as alternatives to coping with risk and uncertainties of livelihoods. Rural households in Nigeria engage in non-farm economic activities such as migration, trading and provision of agricultural services (Barrett al et., 2001; Block, al et., 2001). Such non-farm activities provide insurance against the diverse form of unforeseen risks and uncertainties (Asmah, 2011). This study focused on migration as the nonfarming activities for the rural households. In poor households, in the developing countries income is unstable and they trend to developed different complex strategy to succeed. Migration is one of such strategies. Migration is a form of lucrative venture available for the world poor (Clement and Ogden 2014).In some cases households or individuals or families may take decisions to migrate, for the purpose of getting better opportunities in order to increase the income of the household and reduce the impact of poverty in the family. Poverty is a complex issues relating to household income and livelihood strategy. People may decide to migrate to areas where they presenting better opportunities or other sources of income that may ameliorate living standards. Migration is among the households income diversify method use to mitigate against unforeseen shocks (Giebert 2007; Shonchey2011; Clement and Ogden 2014).The increasing popularity of off-farm prospects in rural areas in Nigeria, demonstrated by the increase in rural enterprises and the rising rural-urban migration, has motivated the empirical research on migration as livelihood diversification strategy of the poor rural household in Nigeria. This study examines migration as strategy taken by households to reduced vulnerability and maximise households income.

\subsection{Reviews of Literature}

\subsection{Livelihood Strategy}


According to Peng et al (2017), livelihood strategies is a term used to describe the combination of activities and choices made by households in order for them to survived and live a good life. Rural households in Nigeria employ different livelihood strategies and activities in order for them to increase their income and create wealth to overcome poverty. Household livelihood is more than monetary resource and complex in nature. Household livelihoods strategies are not completely described simply by income resource (Peng et al., 2017). Ellis (1998) explains that diversification is a strategy employed by poor household in the developing countries to increase their incomes resources. Rural households in Nigeria are constantly involved in diversification as a survival strategy. Diversification provides surplus of income to rural households to invest in agricultural production and other micro enterprise in the rural economy (Assan, 2014).Ellis (2005) explains that there are two forces that drive the causes of rural livelihood diversification, these are agricultural optimistic theory and agricultural skeptic theory. Agricultural optimistic theory believes that the success of agriculture drives the non-farm business activities in the rural areas. While the agricultural skeptic theory is of the disparate opinion, that diversification occurs in response to the failure of agriculture to generate the sufficient resource for the livelihood of the rural households (Kirori, 2018). In rural Nigeria, households depend on agriculture for their livelihoods. The failure of the agricultural sector to generate sufficient income for people in rural area to improve on their standard of living, resulted in the diversification into different economic activities for livelihood. Non-farm diversification is an efficient way for rural household in Nigeria to reduce their income risk and increase their living standard (Ellis, 1998). Financial risk and uncertainty in the agricultural sector plays a strategic role in the diversification process. Income, poverty, welfare risk and lack of social security system in Nigeria are the major push factors that encourage rural household to diversify into migration as a livelihood strategy. Diversification into non-farm activities allows rural household to reduce risk associated with income generation through agriculture (Wouterse and Taylor, 2006). Evans and Ngau (1991) explains that rural households diversified into non-farming sources of revenue serves as risk insurance, enabling them to invest more in the farming input and raise their output. According to Hassein and Nelson (1998), livelihood diversification may be undertaken by the households in other to support the improvement of livelihoods and living standard. Therefore allowing the surplus income generated from the diversification to be invested in a diverse business activities creating more income for the households.

\subsection{Concept of Migration}

Migration refers to the movement of people from one geographical location to another (Ogunmakindle et al, 2015). This movement may be permanent or temporary. The people move from the rural villages to the urban cities in search of better economic opportunities to improve on their living standards. Universal analysis of migration is mostly negative. Internal migration creates a series of issues such as unplanned urbanisation, neglect of agriculture in the rural areas, rural poverty, increased in urban crime. Ogunmakindle et al (2015) explained that potential migrants focus only on the benefit they will accrue from migrating, and not taking into consideration the problem the process will create. Most contemporary literature see internal migration as a problem for development, which can be controlled or contained with the view that internal migration is associated with negativity (Awumbila, 2017). Despite the negative views associated with migration, it has been recognised that migration contributes positively to the development of the sending communities. Migration can have a direct impact on the livelihoods of the rural poor households. It could serve as a social security mechanism for the poor vulnerable households who have low income sources (Mishi and Mudziwapasi 2014).Migration is a crucial part of income diversification strategy by rural and urban households. Migration allows, rural households to receive economic remittance, social remittance and accumulation of assets, and capital for investment (Grune 2017). Social remittance refers information, new practise, and ideas. However, internal migration in Nigeria is far more significant in the number of people involved and is vital in the amount of remittance be sent. The remittances received have high positive potential on poverty reduction among the rural households (Awumbila, 2017).Remittances flows directly into the individual receiving households changing their financial position and increasing their purchasing power instantaneously. Since the early 1980s, it has been identified that migration plays a significant role in the livelihoods of migrant's households. This has spawned much debate about the positive effect of migration on the sending communities despite the challenges presented by migration, such as urbanisation. Migration creates opportunities for migrants from the poor household to make a livelihood and amass wealth for the family (Awumbila, 2017). Migration is one of the actions taken by the rural household to fight against poverty. Rural-urban migration is the leading migration stream among the people in Nigeria. The rural dwellers move from rural areas to the cities in search of social and economic opportunities to make a better life and improve on their living standard. 
According to Awumbila (2017), rural-urban migration has becomes one of the contributors to the level of growth of urbanization in African countries. In Nigeria rural-urban migration has played significant role in the level of expansion and growth of various cities in the country.

\subsection{Theoretical understanding of migration}

In understanding the causes and factors of migration, different theoretical models were designed to explain the same thing using different concepts and hypothesis (Porumbescus 2015). Most of the existing literature on factors of migration, within a given place of origin and destination, predicted that migration results from micro level economic incentives and disincentives created by the larger structural economic changes in the country. The neoclassical micro-economics refers to migration as an individual strategy used for income maximization (Mishi and Mudziwapasi 2014:3).The neoclassical theory is of the view that an individual migrate when the expected wages in the destination is greater than the income of the migrant in the place of origin. Individuals would be expect to migrate when the benefit of moving is greater than that of staying, and the financial return on human capital is high.

\subsubsection{New economic of labour migration theory}

The new economics of labour migration (NELM) propose that households send migrants to migrate in other for them to improve on the household income and increase their standard of living as well as to reduce their relative deprivation with respect to other reference group in their community (Stark and Bloom 1985). According to NELM the rural households make the decision for the member of the family to migrate. The NELM highlights that family is key in migration decision. The individual migrant does not take that decision for migration. It is collectively made by the family unit. Migration is used by the rural household as risk pooling strategy, against any foreseen circumstances (Stark and Bloom 1985). According to NELM, the primary purpose of migration is for the family to receive remittance. The remittance received helps the rural household to overcome poverty and any forms of risk associated with market failure. Migration is a measure taken by the households and community to overcome economic risk and any form of credit. In the Nigeria the government does not provide the households with any form of social security. Thus the rural household takes migration as sources of alternative income for the family. In the case of this study, the poor rural household in rural areas in Edo State takes migration as an income generating strategy for their livelihood survival and to reduce the impact of poverty. Adepoju (2004) explains that migration in Africa is a family affair in which the non-migrants member of the family plays a significant role in the decision making process. In the NELM, the cost benefit calculation of migration is determined by the household. The decision to send migrants is taking by the household. The household send a member of the family to migrate as ways to solve the problem of uncertainty and risk resulting from the market failure. Thus, migration is a means to improve on the well-being of the household and the migrants (Grune 2017). In this study, migration is a strategic plan of the household in the rural area to improve on their economic level and assist the nonmigrant's members of the family to receive remittance and improve on their living standard.

\section{Study Area}

Edo State is a state located in South-South region of Nigeria. The state harbours four major ethnic groups, which are Edo, Esan, Owan and Etsako. The major towns in Edo State include BeninCity, Ekpoma, Auchi, Uromi, 1guebeni, Uzebba, Agenebode, Ughoton, Igueben, Jattu, and Ehoretc. Edo state has two notable climates, which are sub-equatorial with high rain fall for about 7 months and with average temperature of about $29^{\circ} \mathrm{C}$ and less rain fall in the winter. The primary economic activities in Edo state include, farming, local craft, rubber processing, informal trading, palm oil production, and livestock rearing, crude oil production

\subsection{Methodology}

In this study qualitative and quantitative approaches were used for the inquiry into the deeper understanding of the phenomenon of migration as livelihood diversification strategy. Primary and secondary data were analysed in the study. The primary data were collected from a field survey carried out in November 2014 using the questionnaire. 120 questionnaires were administered to rural households in Edo State. 14 key informant interviews were conducted. The key informants were selected using the purposely sampling method. The participants for the questionnaire were randomly selected. The secondary data were derived from journal publications, books and archived materials. 


\section{Results and Discussions}

\subsection{The demographical information of the respondents}

The respondent consist of $(53 \%)$ male and $(47 \%)$ female. The family prefers to send male member of the household to migrate than the female. This means migration is gender selective. The age of the respondents ranged from 15 to 75 years respectively. Human migration is age selective, the younger male or female between the ages of 16 years to 25 years of age move easily that older once due to feasibility and less responsibility attached to them.

\subsection{Migrants Income flows and poverty alleviation}

The flows of income from the migrants to their home of origin are ways of alleviating poverty among the households. One of the objectives of the research was to examine the effect of the income flows of the migrant on alleviating poverty and bringing financial security. According to the World Bank (2007), the role remittance plays in the life of the recipient households is of primary economic benefit to reduce the rate of poverty and increase the potential level of investment in different businesses in that household. Thus, income from migrants has a significant impact on the living standard of the recipients' households. The migration of the youth out of the rural areas to cities has contributed directly to reduction of poverty in the migrants' community through the flow of income to their households and the spill-over effect of the income received. Various studies revealed that remittance sent by migrants to their home of origin has been one of the important benefits that have directly assisted the households. (Ajaero et al., 2014; Odozie, et al., 2010). Siddiqui et al. (2012) indicated that migration has a direct effect on the welfare of the people in the place of origin though the remittance received. Anyanwu et al. (2010) affirmed that remittance sent by migrants to the villages of origin reduced the depth and severity of poverty and helped indirectly to stimulate economic growth of the rural areas. Previous studies in Nigeria on the implication of remittance from migrants on poverty concluded that remittance reduces the share of people living in poverty in the country (Odozie, et al 2010).

\subsection{The effects of income flow on household living standard}

Figure 4.0: Migrants' income flows on their household living standard

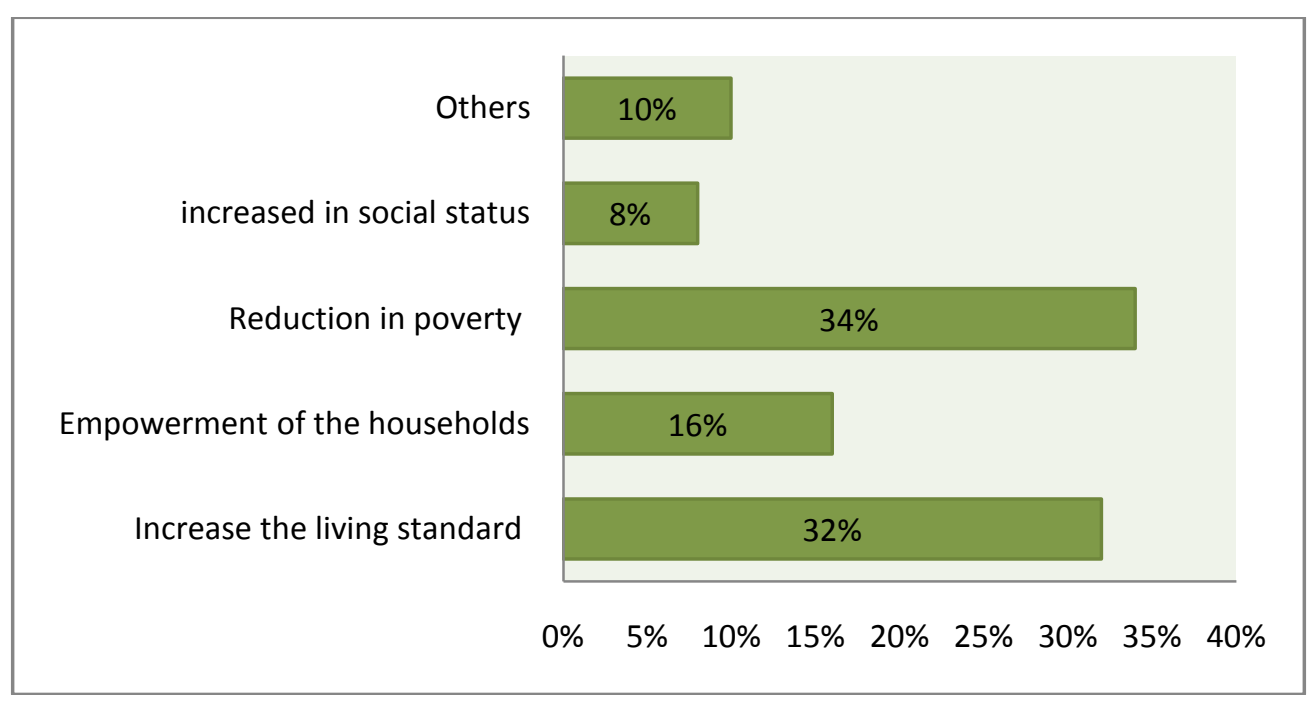

Sources: Author's Field survey November -2014

The flows of income from the migrants have a multiple effect on the livelihood and living standard of the migrant's families. Figure 4.0 illustrates that $34 \%$ of the respondents claimed that the income flows from the migrants has led to reduction of poverty among the family members in their households and in the community, because they now have more money to spend on things they need, while $32 \%$ of the respondents claimed that the remittances they received from the migrants had led to an increase in the standard of living of their families and households. However, working in the cities has also supported about $8 \%$ of the respondents to be living well and to have an increased financial status in the society. The opportunity to be empowered in their households through the flow of income by the migrants was claimed by $16 \%$ of the respondents, while $10 \%$ of the respondents stated that the income flows from the migrants have helped the community. 
The flow of income to the family of the migrants, has led to an increase in the standard of living of household members of the family in the rural community. It has increased their financial well-being and they now have increased financial confidence. Most households receiving the remittances tend to use the proceeds mainly for consumption and also for investment in health care, children's education, and contribution toward the improvement in the household food security. According to one of the key informants, the income flows from the migrants has played an important role in alleviating the poverty and increasing the living standard of the households. This is demonstrated by one key informant who says:

... .I survive primarily on the money my first son who lives in Abuja usually send to me every month to buy food stuffs, medication for my wife and for the payment of the school fees of my youngest son that lives with me. My wife has been sick for some time now and I am no longer resilient enough to carry on with my daily work as a driver. My youngest son has to come and lives with me to take care of me and his mother. (Interview with key informants in Ehor, 12 November. 2014).

Different livelihood strategy will increase the welfare level of rural household and also creates growth in nonfarm employment (Peng et al., 2017).Rural-urban migration can largely reduce the dependency of rural household on agriculture.

\subsection{Remittances and their impact on poverty alleviation}

Remittances are considered as essential sources of income for the migrants' households who invest some part of the income and spend some part of it on consumption expenditures. Remittance incomes also improve the basic needs of the household and the living standard of their families. They provide a foundation for the household to have a sustainable income security. Remittances assist in empowering, the household to overcome poverty. As one of the objectives of the research was to ascertain the effect of the income flows of migrants on the alleviation of poverty and financial security, Figure 4.1 indicates the responses of the respondents on the income flows on alleviation of poverty.

Figure4.1: The roles of remittance in poverty alleviation in the villages

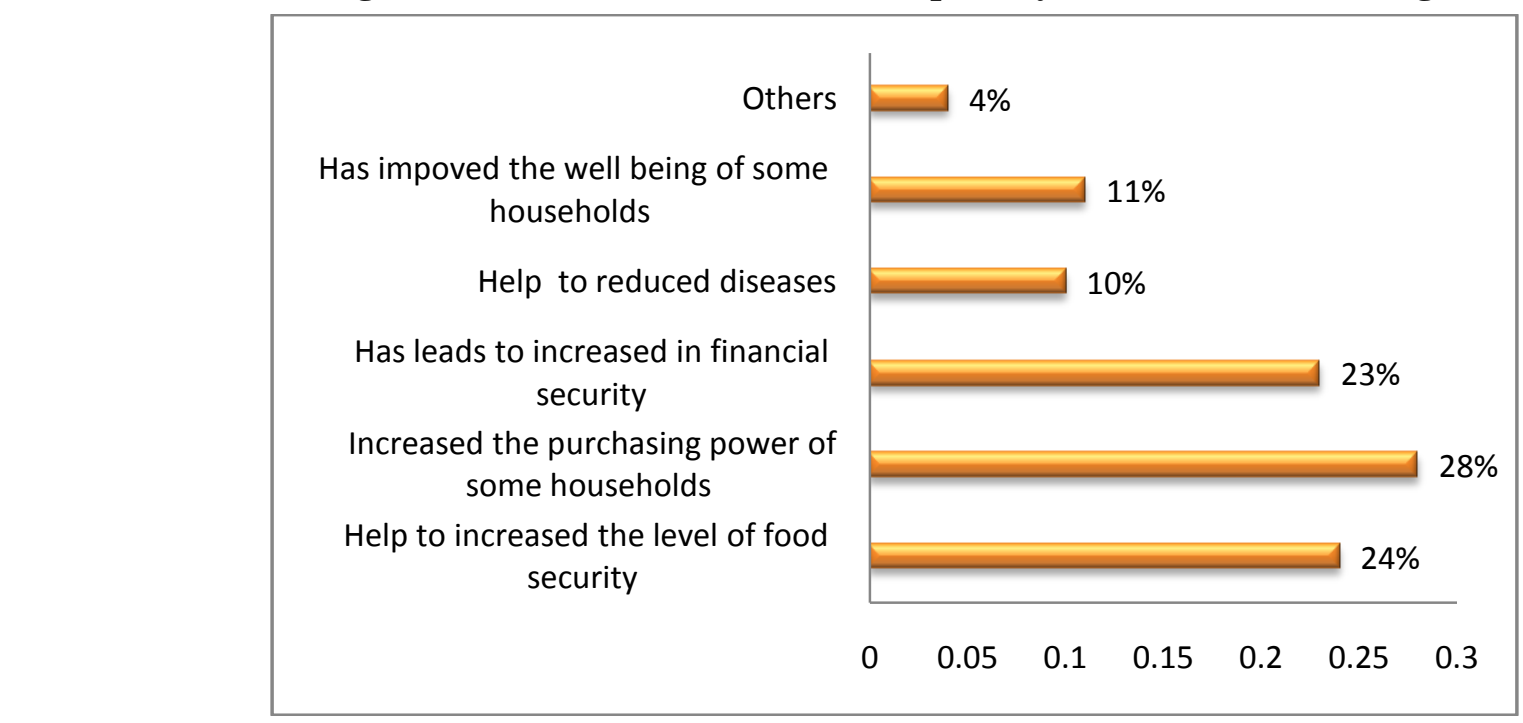

Sources: Author's Field survey November -2014

Figure 4.1 shows that the larger proportion of the respondents (28\%) claimed that remittances received by the migrant's families have increased the purchasing power of some of the households in the community, while $23 \%$ of the respondents were of the view that remittance received had led to an increase in financial security among the households making them more comfortable and living above poverty. Twenty-four percent (24\%) of the respondents stated that the income flows from the migrants as remittance has led to the increase in the food security in the community and the rural households are now able to invest more into food production. In addition, $11 \%$ claimed that the income flows of the migrants in the forms of remittances has made them and their respective household to better off and now have a better life. Moreover, 10\% stated that the income flows from the migrants has led to the reduction in the spread of disease, because the family is able to eat well and some projects in the community carried out through the support of the remittance has led to the improvement in accessing welfare facilities. 
Four percent $(4 \%)$ of the respondents claimed that the income flows from the migrants has created a better living standard for them, enabling them and their household to have a good life.

A key informants indicated that two members of their household were send to Port Harcourt to work so that they will be able send money home to assist the family as stated below..

....... Two members of my household, my eldest son and my younger brother were sent to Port Harcourt three years ago to work. Now they are able to support the family financially, my eldest son sent money to me four months ago to rebuild part of my house that was destroyed by fire last year. Also my younger brother always sends me money every month, now I am are able to pay the school fees of my daughter who is in the university. We also spends part of the money on food and clothes (Interview with key informants in Ehor, 14 November. 2014).

Analysing the key informant's interview, the family took migration as a livelihood strategy. This is in line with the livelihood approaches which argued that people developed a livelihood strategy in their life; they make choices on the various strategy to survival (Grune, 2017; Da Haas, 2010). This also supports the NELM claims that the cause of migration is lacks of social security, investment opportunity, credit and insurance. Thus migration was a way for families in the rural areas in Edo State to diversify the risk in their household. In Nigeria, households take migration as an alternatives way to secure their future income due to missing social structures by the government.

Previous studies on rural poverty reduction have indicated that alternative livelihoods strategies have a direct positive implication on alleviation of poverty (Peng et al., 2017). Rural household that are involved in non-farm livelihood strategies were able to earn more income (Peng et al., 2017).

\section{Conclusions and recommendation}

The findings from the study divulge that rural households employ migration as an income diversification strategy to increase their source of income and improve on livelihood. The rural household diversification of income was necessary due to the failure of the agriculture to generate sufficient resource for the household to overcome poverty. Thus, rural income diversification contributes to the growth of rural economy. Migration contributes to the improvement in rural household income potential in Edo States to improve on their livelihood standard. The study found that remittance income received from the migrants played significant roles in increasing the income of the rural household in rural communities in Edo State. The remittance income increases the standard of living of the rural households. It also contributes to increased household potential to invest in micro-enterprise in the rural area. Migration plays a significant role in reduction of the level of poverty among the rural household. The study therefore recommends that measures should be put in place by the various stakeholders to exploit the developmental potentials of the remittance. Adequate measures should be put in place by the government to improve on the rural banking infrastructure in the country to facilitate the easy transfer of money to the rural areas.

\section{References}

Anyanwu, J.C., and Erhijakpor, E.O. (2010). Do remittances affect poverty in Africa?, African Development Review, 22(1): 51-91.

Ajaero, C. K. \&Madu, I. A. (2014). Rural-Urban Migration and Livelihoods in South Eastern Nigeria. Developing Country Studies, Vol.4, No.6.

Adepoiju, Aderanti, (2004). 'Trends in International Migration in and from Africa', International Migration: Perspectives and Policies in a Global Market, Ed. Massey, Douglas S. and Taylor, J. Edward, Oxford University Press.

Asmah Emmanuel Ekow, (2011). Rural livelihood diversification and agricultural household welfare in Ghana. Journal of Development and Agricultural Economics Vol. 3(7), pp. 325-334, July 2011 Available online at http://www.academicjournals.org/JDAE

Assan, k. Joseph, (2014). Livelihood Diversification and Sustainability of Rural Non-Farm Enterprises in Ghana. Journal of Management and Sustainability; Vol. 4, No. 4

Awumbila Mariama, (2014).Drivers of Migration and Urbanization in Africa: Key Trends and Issues, Centre for Migration Studies, University of Ghana 
Barrett, C., Bezuneh, M. \&Abdillahi, A. (2001a). Income diversification, poverty traps and policy shocks in Cote d'Ivoire and Kenya. Food Policy, 26 (4), 367-384.

Block, S., \& Webb, P. (2001). The dynamics of livelihood diversification in post-famine Ethiopia. Food Policy, $26(4), 333-350$.

Clemens Michael and Ogden Timothy, (2014). "Migration as a Strategy for Household Finance." CGD Working Paper 354. Washington, DC: Center for Global Development. http://www.cgdev.org/publication /migration -strategy-household-finance-researchagenda-remittances-payments-and

De Haas, Hein, (2010). 'Migration and Development: A Theoretical Perspective', pre-print version for International Migration Review, Vol. 44 (1)

Evans, H.E. and Ngau, P.M., (1991), 'Rural-urban relations, household income diversification and agricultural productivity', Development and Change, 22(3): 519-545.

Ellis, F. (1998). Household Strategies and Rural Livelihood Diversification. Journal of Development Studies, 35(1), 1-38. http://dx.doi.org/10.1080/00220389808422553

Ellis, F. (2005), Small Farms, Livelihood Diversification, and Rural-urban Transitions: Strategic Issues, In SubSaharan Africa, paper presented to the IFPRI/ODI/Imperial College Conference of the Future of Small Farms, Wye, UK.

Grüne, Ann-Jolin, Franciska, Adele,( 2017). To What Extent Does the New Economics of Labour Migration Theory (NELM) Explain Refugee Remittances? A Case Study of the Cause of Migration and Remittances Sent by Somalis in Finland. Master's Thesis, Department of Political and Economic Studies. University of Helsinki, Finland.

Siddiqui, t. (2012). Impact of migration on poverty and development. Refugee and migratory movements research unit (rmmru) migrating out of poverty research programme consortium working paper 2 September 2012. University of Sussex, United Kingdom.

Stark, O., Bloom, E. D. (1985). The New Economics of Labor Migration. The American Economic Review, 75 (2): 173-178.

Stark, O., \&Levhari, D. (1982). On Migration and risk in LDCs. Economic Development and Cultural Change, 31(1), 191-196. Retrieved from http://www.jstor.org/stable/1153650.

Kirori N. Gabriel, (2018). Social Capital in Kenya: A Strategy for Rural Development Journal of Economics and Sustainable Development, Vol.9, No.12, 64-74

Taylor, J.E. (1999). The New economics of labour migration and the role of remittances in the migration process. International Migration, 37(1), 63-88. DOI: 10.1111/1468-2435.00066.

Mishi, Syden and Mudziwapasi, Lilymore, (2014). Remittances and sustainability of family livelihoods in Zimbabwe: Case Study of Chegutu Town. Economic Research Southern Africa (ERSA) working paper 440, May 2014

Hussein, Karim and Nelson, John, (1998). 'Sustainable Livelihoods and Livelihood Diversification', Institute of Development Studies University of Sussex (IDS) Working Paper 69

Odozia, J.C., Awoyemia, T., and Omonona, B.T. (2010). Household Poverty and Inequality: The Implication of Migrants' Remittances in Nigeria; Journalof Economic Policy Reform 13 (2): 191—99.

Peng Wenjia, Zheng Hua, Robinson Brian E, Li Cong, and Wang Fengchun, (2017).Household livelihood strategy choices, impact factors, and environmental consequences in Miyun reservoir watershed, China. Journal of Sustainability (9) 175

Wouterse, Fleur and Taylor, J. Edward, (2006). Migration and Income Diversification Evidence from Burkina Faso. Paper prepared for presentation at the International Association of Agricultural Economists Conference, Gold Coast, Australia, August 12-18. 